\title{
CÂTEVA ARGUMENTE PENTRU UNIREA ROMÂNILOR ÎN PUBLICISTICA LUI M. EMINESCU DIN ZIARUL "TIMPUL"
}

\section{Anca Doina Sîrgie}

Moto: "După părerea noastră dezvoltarea poporului român nu vaputea să intre pe calea ei normală câtă vreme trăim despărțiți. "(I.Slavici)

Atunci când citești poezia Ce-ți doresc eu ție, dulce Românie, pe care Mihai Eminescu o concepuse la 16-17 ani, în perioada peregrinărilor lui adolescentine, străbătând adesea cu pasul drumurile din Bucovina în Transilvania, riști să consideri că poetul fusese inspirat de un entuziasm naţional de moment. În realitate, el identifica nu o provincie, ci cuprindea în sintagma "dulce Românie” întregul contur al vechii Dacii, așa cum țară străbunilor fusese sub Regele Burebista și Decebal. Admirăm şi astăzi solemnitatea strălucită a poematicei urări, neîntrecută în literatura română de vreun alt poet: "Ce-ţi doresc eu ţie, dulce Românie, / Ţara mea de glorii, ţara mea de dor?/ Braţele nervoase, arma de tărie, /La trecutu-ţi mare, mare viitor!// Fiarbă vinu-n cupe, spumege pocalul, /Dacă fiii-ţi mândri aste le nutresc;/Căci rămâne stânca, deşi moare valul, / Dulce Românie, asta ţi-o doresc." În ciuda vremelnicei divizări în provincii separate, cu nume distincte, "țara de dor" a tuturor conaționalilor poetului era Dacia Mare. $\mathrm{Cu}$ genialitatea sa proiectivă, el pivotează imagistic pe proverbul „Apa trece, pietrele rămân" inspirat transpusă în formularea cu valoare conclusivă „Căci rămâne stânca, deşi moare valul" și atât de memorabil cântat de Sava Negrean Brudașcu în melodia patriotică bine cunoscută astăzi. Așadar, Ce-ți doresc eu ție, dulce Românie este crezul politic și programul de luptă pe care și-1 formula strălucit tânărul poet. Se găsesc aici liniile directoare ale viitoarelor

\footnotetext{
${ }^{1}$ Vezi Gh. Panu, Amintiri de la Junimea din Iași, vol. II, Editura Minerva, București,
}

abordări din publicistica sa, activitate permanentă de om al cetății, începută în anii studenţiei şi prestată în publicaţii diverse din toate provinciile, dar culminând ca redactorșef al ziarului "Timpul” din București.

PASIUNEA PENTRU ISTORIE A LUI M. EMINESCU

El afirmă aceasta ca bun cunoscător al trecutului românesc, spre care şi-a îndreptat cu pasiune atenția încă din anii de școală și în răstimpul care a urmat cu aceeași preocupare consecventă, după cum o dovedește în planul creației poetice și acea sinteză pe care o va cuprinde în poemul Scrisoarea III, moment și monument unic în perimetrul liricii naţionale pe teme patriotice.

În mod indelebil, ziaristul Eminescu își dovedește autoritatea prin felul cum comentează în publicistica sa istoria medievală a românilor, pe care o prețuia la superlativ, dovedind că o cerceta cu pasiune și nu pregeta să facă mărturii edificatoare în faţa celor apropiați. În cartea memorialistică rămasă de la el, Gh. Panu a notat sfatul lui Eminescu: "Panule, să ştii tu că în lumea asta nu este nimic mai interesant decât istoria poporului nostru, trecutul lui..." "Făcând "autopsia istoriei naționale" așa cum apărea ea în ziarul "Românul", publicistul Eminescu constată autoritar că acolo în mod cu totul regretabil se falsifică adevărul, căci după acea opinie "orice Domn bun întâlneşte în cale e reacționar, e turcofil, iar oricare taie capetele boierilor e național și liberal.” De aceea el va 
continua la modul ironic: "Presimţim că și Mihai Viteazul și Matei Basarab vor fi trecuţi în registrul negru, iar Mihnea cel Rău şi Mircea Ciobanul, descendenții armaşului Dracea, vor fi schimbați în martiri ai libertății poporului."2 Preocupat de mecanismele care au dinamizat viața acestor principate dunărene în vremea voievodului Mihai Viteazul, primul unificator al românilor, Eminescu explică de ce era necesară acea Glebae adscriptio/ legarea de pământ/, ca hotărâre generalizată în Europa timpului împotriva despopulării, act sancționat cu drasticitate de istoria modernă a românilor. Poate tocmai de aceea este interesant să înţelegem punctul de vedere al ziaristului român din secolul al XIX-lea, care comenta astfel controvestata decizie voievodală din veacul al XVI-lea românesc, prezentată de el în context european: "Mihai Viteazul a luat dar o măsură pentru a fixa populația șesurilor, ba a așezat chiar colonii. Un domn avizat a se lupta cu toată lumea, deci a avea o oaste, trebuia să fixeze în loc poporul pe care-și întemeia și bugetul şi armata. Aceasta este explicarea adscripțiunii la noi, tot acest înţeles îl are edictul lui Ivan cel Cumplit. Rusia ar fi rămas un ocean de triburi în vecinică migrațiune fără edictul care le-a fixat pe toate de pământul cui s-o găsi.Tot aşa ar fi rămas șăsul Țării Românești." 3 În vremea lui Mihai nu erau răzeși ca elemente statornice, ci țara era bântuită de tătari și turci, aşa că "el a adus orânduială unde era caos.”Analiza, făcută la nivelul esențializant al unui articol menit să informeze publicul cititor al acelui timp, dovedește că Eminescu se baza pe cunoașterea situaţiei de criză financiară provocată de prea desele atacuri otomane în timpul domniei lui Mihai Viteazul, susținând argumentarea logică a legării de pământ a țăranilor valahi. Fără această măsură deloc populară, dar absolut indispensabilă

\footnotetext{
${ }^{2}$ M.Eminescu, Erodot al "Românului" continuă, în "Timpul" din 25 ianuarie 1881, în Opere, vol. XII, Publicistică 1 ianuarie 31 decembrie 1881, Editura Academiei Române, București, p.43.
}

continuării respingerii militare a turcilor, nu sar fi putut continua cu succes politica antiotomană care face din Mihai Viteazul "steaua răsăriteană" a apărării țărilor Europei. Într-un document din 6 iulie 1600 Mihai apare ca "Domn al Țării Românești și Ardealului și a toată țara Moldovei", dovedind, aşa cum s-a stabilit abia începând din istoriografia secolului al XIX-lea, că a făcut o unire personală a celor trei provincii române, ca vizionară preludiere a Marii Uniri din 1 Decembrie 1918.

În articolele lui Mihai Eminescu din ziarul bucureștean „Timpul”, ziar la care a activat în perioada 1877-1883 cu tensionata situaţie politică a Regatului României și a celorlalte provincii românești, apar referiri la istoria, care a dat neamului nostru o anumită identitate: "Un popor care a avut nefericirea de-a fi guvernat o sută douăzeci și unu de ani de străini și care, prin această împrejurare, a trebuit să-și piarză simţul său istoric și conștiința marilor datorii către stat, ce erau legate de vechea organizare socială, nu mai admite, nici poate admite o organizare pe clase, cari se distingeau nu prin mulțimea drepturilor, ci prin gradul datoriilor." Publicistul ajunge pe baza acestei scrutări a istoriei la concluzia că destinul modern al neamului său este marcat de drama care i-a fost hărăzită prin dominarea fanariotă. Un interesant punct de vedere, logic argumentat în publicistica eminesciană, este cel de a elimina perioada fanariotă din istoria națională "pentru că acei domnitori nu erau aleși de boieri, armată și popor, nația nu era legată prin jurământ către Domnii fanarioți, ei erau numiți ca guvernatori de către turci, autoritatea lor e uzurpată, e pân-în sâmburele ei ilegitimă. Şi oricine a ridicat brațul în contra lor a făcut o faptă bună și lăudabilă." 5 Ziaristul de la "Timpul" nu poate accepta asimilarea perioadei fanariote în fluxul firesc

${ }^{3}$ Ibidem, p. 44.

${ }^{4}$ M.Eminescu, Discuția iscată..., în

"Timpul" din 14 ianuarie 1882, în Opere, XIII, Publicistică , 1882-1883, 1888-1889, Editura Academiei R.S.R, 1985, p. 31. ${ }^{5}$ Ibidem, p. 45. 
al evolutiei istorice a neamului său, ci o desemnează ca pe o excrescență străină, cu totul păgubitoare progresului național.

Cunoscând îndeaproape situaţia esteuropeană contemporană, Eminescu își exprimă cutezător propria convingere, luând o atitudine clară împotriva unor mari puteri ca Austria habsburgică sau Germania lui Bismarck, cu orice risc, chiar fiind conștient de consecințe. În Raportul nr.3 al consulului Hans Wenzl, trimis de Imperiul AustroUngar la Iași, la 5 ianuarie 1877 i se dau infomații contelui Gyula Andrassy ${ }^{6} \mathrm{cu}$ referire la seria de conferințe publice organizate de Mihai Eminescu, inaugurate la finele lunii noiembrie 1876 în capitala Moldovei, unde el activa ca profesor la universitate şi era redactor al buletinului oficial "Curierul de Iaşi“". Prima conferință avusese ca temă situația românilor în AustroUngaria. Publicul numeros "a urmărit expunerea cu curioasă luare aminte și a gratulat conferențiarul $\mathrm{cu}$ aplauze zgomotoase".Conținutul conferinței este urmărit în detaliu și se consemnează atitudinea oratorului faţă de statul dualist:"el crede că politica pe care o exercită AustroUngaria față de naționalităţi în general, dar în special față de cea română, este discutabilă.“ Ministrului i se aduce la cunoștință până și faptul că acea cuvântare a fost publicată în ziarul "Curierul de Iași“" ziaristului Eminescu era deloc ocazională, ci permanent şi nu venea doar de la autorităţile externe, ci și de la conaţionali precum F.A. Cantacuzino care îl avertiza pe Titu Maiorescu că trebuie să-l pondereze ca atitudine:"Fără a-I spune nimic care să-i poată deștepta susceptibilitatea sau sensibilitatea, să obții din partea sa nu ca să spună adevărul, ci să nu-1 spună decât în mică parte. “8 Presiunea care venea în mod concertat din toată părțile asupra conștiinței ziaristului trebuia să facă

\footnotetext{
${ }^{6}$ Gyula Andrassy a fost ministru de externe al monarhiei dualiste între 1871 și 1879.

${ }^{7}$ Raportul nr.3 al lui Hans Wenzl către Andrassy, în "Cugetarea Europeană/La pensee europeenne“", Supliment literar nr.2, 2018, p. 6.
}

din analistul politic o marionetă pusă în slujba unor potentaţi. Stratagema iniţiată în 18791880 nu dă rezultate, din moment ce câțiva ani mai târziu sfatul lui Petre Carp, aflat la Viena, suna mai repede a ordin: "Mai potoliți-l pe Eminescu odată" nu a rămas fără urmări. În "Timpul" ziaristul tocmai demascase umilitoarele condiții impuse de puterile europene României, care nu mai putea revendica Transilvania, conform convenției pe care o semna cu aliații secreți Germania, Austro-Ungaria și Italia. Înțelegând că singura armă în lupta pe care o purta era cuvântul său de gazetar, Eminescu pune accentul pe ceea ce afirmă în articolele sale de atac concertat împotriva afacerilor veroase ale vremii și pentru sprijinirea idealului de unitate a poporului român. Articolul său cu titlul lui premonitoriu, ca ultim elogiu fãcut dreptului la liberă opinie, Pentru libertatea presei și a jurnalistului, era o reacție curajoasă la hotârârea guvernului Brătianu de a expulza pe ziaristul Emil Gall, concomitent cu desființarea în 28 iunie 1883 a Societății "Carpații", la care Eminescu se numărase printre fondatori în 24 ianuarie 1882 . Societatea secretă "Carpații” avea obiectivele unui proiect unionist într-o vreme de mare urgie din secolul constituirii naţiunilor.

\section{IDEALUL UNITĂȚII ÎN STUDENȚIA LUI EMINESCU \\ Cel ce făcuse din afirmația că "Unitatea} românilor este visul meu de fier" ideal suprem, devenit linia cardinală a atitudinii sale jurnalistice, activase ca student la Viena în Societatea "România Jună", care se constituise din alte două, anterioare, numite semnificativ "Românismul", organizaţie orientată, ca și “Orientul” de la București, spre culegerea folclorului, şi "România". Niciodată el nu a ezitat să-și exprime convingerile politice. Astfel în aprilie 1870 el

${ }^{8}$ Scrisoarea lui F.A.Cantacuzino către Titu Maiorescu/1879-1880, București joi, 19/31 oct., în"Cugetarea Europeană/La pensee europeenne“, Supliment literar nr.2, 2018, p.7. 
publică în "Federațiunea" de la Pesta articolul Echilibru, pledând pentru autonomia Transilvaniei. Ca urmare, procurorul îl citează sub acuzația de instigator. Ar fi greu să decidem care era pe atunci prioritatea sa interioară, din moment ce, abia remarcat ca poet de real talent în 1866, el se afirma și ca lieder de opinie, ca luptător naţionalist prin cuvântul său de ziarist. Și nu doar în acest plan își exprima studentul Eminescu convingerile prounioniste. Se știe că în august 1871 studentul Eminescu făcea parte din comitetul de organizare a serbării de la Putna, el acționând pe ambele căi pentru ideea uniunii naționale. Ca poet scrie Poemul de la Putna, în care deplânge pierderea pământurilor românești înstrăinate şi îndemnând tinerii la luptă pentru unitate națională. Dragostea de țară țâşnește din fiecare vers: "Virtutea românească, virtutea strălucită/De patrie şi lege, aici în sanctuar/ Se ştie-nmormântată. $\quad \mathrm{O}$ dalbă zi-i sosită. Poporul stă-n genunche s-o-nvețe la altar."

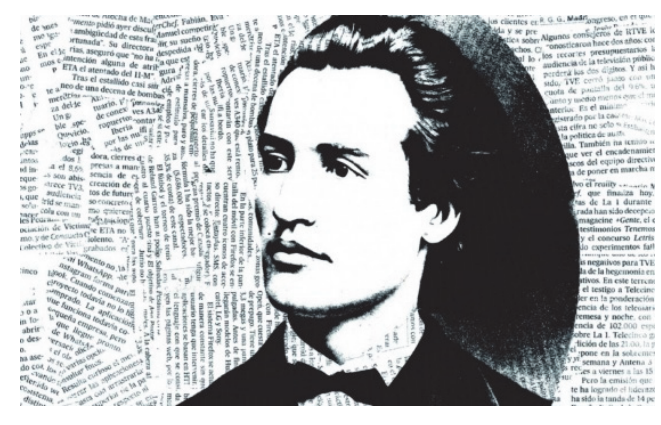

ACȚIUNEA CONCERTATĂ A JURNALISTULUI ŞI A OMULUI CETĂŢII

Ca jurnalist, el scrie în 11 și 18 noiembrie 1877 la ziarul "Timpul" două articole în apărarea membrilor Societăţii “Arboroasa“, care fuseseră arestați pentru acțiunile lor patriotice. În acele articole Eminescu

${ }^{9}$ M.Eminescu, Argumentul de căpetenie... În "Timpul", 1 martie 1878, reprodus în Opere, vol. X, Publicistica 1 noiembrie 1877-15 decembrie 1886, Editura Academiei R.S.R., 1989 , p.55.

${ }^{10}$ M.Eminescu, Fără a prejudeca hotărârilor..., "Timpul”, 28 ianuarie 1878, înOpere, vol. X, Editura Academiei, 1989, dovedise că stăpânește noțiunile juridice necesare apărării bucovinenilor care luptau pentru autodeterminare. Pe o aceeași linie, el afirma în ziarul "Timpul" din 1 martie 1878 convingerea bazată pe o profundă cunoaștere a istoriei:"'Cu sabia n-a fost luată însă, nici Bucovina de austrieci, nici Basarabia de ruși, ci prin fraudă." $9 \mathrm{O}$ asemenea remarcă primejdioasă propriei libertăți nu mai era pentru cititorii ziarului bucureștean o noutate, ci atitudinea de frondă împotriva Rusiei, care ocupase samavolnic Basarabia, răzbătea din toate articolele publicistului care se transforma într-o porta-voce a întregului său popor:'Nu voim s-auzim de nici un aranjament cu Rusia, nu-i concedem dreptul de a trata în numele nostru, căci n-am însărcinat-o nici noi cu aceasta, nici puterile europene. “10 În timpul Războiului de independență, el pledează în mod clar pentru revenirea Bucovinei, Basarabiei și Transilvaniei la patria-mumă, spre a fi reconstituită Dacia Mare. Visul unirii principatelor 1-a animat întreaga viaţă. $\mathrm{Nu}$ este întâmplător faptul că Eminescu lucra în ultimii săi ani de activitate să înființeze Societatea "Matei Basarab", care avea drept țel tocmai unirea tuturor românilor într-un singur stat. Corespondenţa pe care ambasadorul austriac baron von Mayr o întreținea cu ministrul de externe al Imperiului Austro-Ungar, nu altul decât contele Gustav Kalnoky ${ }^{11}$ conţine date exacte referitoare la urmărirea activității lui Eminescu la "Societatea Carpații". În 7 iunie 1882 ministrului i se raportează:”...Eminescu Hauptredakteur des "Timpul" machte den Vorschlag die Siebenburgische Studenten rumanische Nationalitat welche zu ihrer Ausbildung die heiligen Lehranstalten frequentieren fur die Dauer ihrer Ferienreise in

p. 42.

${ }^{11}$ Timp de 16 ani, respectiv între 1881 şi 1895, Gustav Kalnoky a fost ministrul afacerilor externe al Imperiului AustroUngar, el încheind în 1883 tratatul cu România, care urma să adere la "tripla alianță” creată în 1882 între GermaniaAustro-Ungaria și Italia. 
die Heimat mit Bearbeitung das offentlichen Meinung fur ein Grand-Dacien zu betrauen." ${ }^{\text {"12 }}$ Se semnalează adeziuni din toate cele trei tări române la ideaa României Mari. Nici Astra nu rămâne nesupravegheată, așa cum dovedește prefectul Comitatului Brașov în raportul său către ministru din 27 iunie 1883, document în care se precizează că "populația română din țară/Transilvania (n.n.)/ este mai agitată ca de obicei din cauza atmosferei din România."Nu lipsesc măsurile concrete:"Ocazia adunării generale poate fi folosită pentru manifestații și consfătuiri. Ca să pot controla acțiunile, vă rog, prea-onorate, să-mi notificați pe acei români care se ocupă preponderant de agitarea românilor din Ardeal."13

- El știa ce va urma, intuind ce soartă îl aşteaptă și pentru că se simțea amenințat, lui Eminescu îi încolțește gândul de a se călugări la o mânăstire apropiată de capitală, pentru ca de acolo să pornească un atac mai virulent împotriva politicienilor malonești ai vremii sale. Nu a apucat să-și ducă gândul acesta salvator până la capăt, dar nici nu a depus armele. În consecință, pentru că mărturisise lui T. Maiorescu intenţia sa de călugărire, Eminescu a fost catalogat drept extravagand, chiar nebun și discreditat, apoi eliminat din viața jurnalistică românească. De ce? Se acreditează în cercetarea de dată recentă tot mai evident opinia că Eminescu era temut pentru ideile lui unioniste, de refacere a Daciei Mari. Activitatea sa în deceniul al 9lea în cadrul Societății "Carpațiii", care trimitea de la București pe tinerii studenți ardeleni la preoții și dascălii români din Transilvania cu mesaje unioniste i-a înrăutățit pozitiia, iar ordinul camuflat al lui Petre Carp de la Viena "Mai potoliţi-1 pe Eminescu" a cerut măsuri aspre și urgente, impuse cu începere din 28 iunie 1883, când efectiv el

\footnotetext{
${ }^{12}$ Traducere: Eminescu redactor șef la "Timpul" a făcut propunerea ca studenții ardeleni de naționalitate română care pentru perfecționarea lor frecventează școlile preoțești, pe durata vacanțelor lor în patrie să li se încredințeze sarcina de a prelucra opinia publică pentru o Dacie Mare. În"Cugetarea Europeană/La pensee europeenne“,
}

este forțat să înceteze activitatea sa de ziarist. La câteva zile, respectiv în 1 iulie 1883 el publică poezia Doina, apreciată a fi fost "testamentul său patriotic", dezvăluind ideea -axă a luptei sale, cea de conservare a identităţii noastre naționale.

Internat abuziv în diferite sanatorii de boli psihice, la Mânăstirea Neamt, unde i-au fost administrate cantităţi enorme de mercur, după tipicul medical al vremii, şi unde a fost „tratat” prin bătăi cu funia udă, până la leşin, el a fost oprit să mai scrie și să publice. Tentativele sale de descarcerare au fost programatic și constant contracarate, astfel că un ceas înainte de moarte se declara cu luciditate maximă a fi un "om năruit".

Vecinătatea cu Basarabia nu a fost pentru moldoveanul Eminescu doar o realitate geografică, ci l-a ajutat să înțeleagă unitatea istorică și culturală a neamului său de pe ambele maluri ale Prutului.Studiul consacrat Basarabiei, apărut în "Timpul" din martie 1878, are la bază o documentare impresionantă, demnă de o lucrare de doctorat a timpului său, pornind de la Istoria critică $a$ românilor și arhiva istorică a României de B.P.Hasdeu, documentele fondului Eudoxiu Hurmuzaki, cronicile editate de M.Kogălniceanu, Cronica Huşilor de P.S.S. Melchisedec, cartea consulului englez Wilkinson, semnalată și de Al. Odobescu etc. Numai atunci când documentarea sa era îndestulătoare, publicistul înțelegea să formuleze opinii despre trecutul românesc. Referindu-se la epoca înfloririi voievozilor Basarabi, Eminescu conchide bazat pe argumente edificatoare că 'Destul numai că, într-o vreme în care abia era viață istorică prin împrejurimi, Basarabia actuală era pământ românesc stăpânit de Domni români..." ${ }^{14} \mathrm{Cu}$ referire la secolul al XIX-lea când ocupația

Supliment literar nr.2, 2018, p. 8.

${ }^{13}$ Raportul Prefectului Comitatului Brașov, în "Cugetarea Europeană/La pensee europeenne“, Supliment literar nr.2, 2018, p.9.

${ }^{14}$ Idem, I. Basarabia. Numele si întinderea ei. În vol. Ne e silă. Scrieri politice, Editura SOROC, București, 1991, p. 8 
rusească este nelegitimă, publicistul de la „Timpul” imaginează o punere în balanță și astfel:’De brațul scurt sau present al cântarului ar atârna în greu Rusia, de brațul cel lung al unei istorii de 500 de ani atârnă România cu drepturile sale străvechi și nouă. ${ }^{15}$ Cunoscător îndeaproape situația istoriei europene la început de secol al XIXlea, ziaristul demonstrează argumentând logic că anexarea în 1812 a Basarabiei, ca pământ românesc, pe care rușii nu l-au cucerit cu sabia, va concluziona în numele adevărului:,,Se ştie că diplomaţia engleză, împreună cu vânzarea beiului grec Moruzi, a fost cauza cesiunii Basarabiei”. ${ }^{16}$ Atunci când în 1878 generalul Ignatieff a propus guvernului României să cedeze la schimb o parte din Basarabia rămasă, Eminescu ia atitudine, constatând cât de grea devenise situaţia țării noastre, aflate în pericolul de a fi spoliată tocmai de aliatul ei, cu care semnase un acord ce garanta integritatea statală, dar din care tocmai zburau asigurările date "ca pleava-n vânt”, deși semnăturile nici măcar nu se uscaseră pe documentul cu înțelegerea întocmită între cele două state beligerante. Nici Austria, care avea nevoie de neutralitatea Dunării de Jos nu avea liniște, atât timp cât convențiile se şterg cu asemenea uşurinţă. România a pierdut 15.000 de oameni şi „câteva zeci de milioane cheltuieli de război”, o jertfă imensă dată pentru ,mandatarul Europei”, cum era Rusia „în îndeplinirea sacrei sale misiuni”. Așa s-a întâmplat ca „noi să fim cu pagubă, tot noi să plătim războiul Rusiei cu pierderea unei provincii..." În realitate, România nu doreşte să facă niciun schimb de teritorii, drept care „ne astupăm urechile la orice propunere de schimb în această privinţă", publicistul luându-și dreptul de a exprima voinţa întregii țări. Aceasta pentru că drepturile noastre asupra întregii Basarabii ,sunt prea vechi şi prea bine întemeiate", ca să ni se vorbească fără niciun drept „de onoarea Rusiei angajată prin Tratatul de la Paris". De aici, concluzia că

\footnotetext{
${ }^{15}$ Idem, Basarabia. VI. Veacul al nouăsprezecelea. Izvoare. În Op. cit., p.33. ${ }^{16}$ Apud. Gicu Manole, Mihai Eminescu și
}

Basarabia era toată a poporului român încă de la începutul istoriei şi de ,pe când Rusia nu se megieşa cu noi". Basarabia întreagă ni se cuvine toată, întreagă căci e pământ sfânt şi drept al nostru ,cucerit cu plugul, apărat cu arma a fost de la începutul veacului al patrusprezecelea încă şi până în veacul al nouăsprezecelea". ${ }^{17}$

Pierderea pe care o suferise România prin răpirea Basarabiei era incomensurabilă, întrucât "Rusia nu se mulțumește de a fi luat o parte mare și frumoasă din vatra Moldovei, nu se mulțumește de a fi călcat peste granița firească a pământului românesc, ci voiește săși ia și sufletele ce se află pe acest pământ și să mistuiască o parte a poporului român. Rusia nu a luat această parte din Moldova pentru ca să-și asigure granițele, ci pentru ca să înainteze cu ele, și nu voiește să înainteze decât spre a putea stăpâni mai multe suflete. Tocmai puși față în față cu viața rusească, românii au început a fi cu atât mai vârtos pătrunși de farmecul vieții lor proprii, de bogăţia și superioritatea individualităţii lor naționale; tocmai fiind puși în contact cu rușii, românii erau mândri de românitatea lor. E nobil răsadul din care s-a prăsit acest mic popor românesc, și, deși planta nu e mare, rodul e frumos și îmbelșugat; cele două milioane de români au adunat în curgerea veacurilor mai multe și mai frumoase comori decât 90 de milioane de ruși vor putea să adune cândva." Mândru să afirme superioritatea vădită a individualității neamului său față de colosul de la Est, Eminescu relatează în diferite articole modul cum în școli, în biserici ale Basarabiei și chiar în viața de familie a fost interzisă folosirea limbii române, interdicție pe care o socotește chiar mai distructivă decât cea impusă de turci asupra popoarelor cotropite, pentru că ea stagnează evoluția legică și firească a neamului.

Din călătoriile sale timpurii în Transilvania, în mintea lui Mihai Eminescu sa fixat deja ideea apartenenței legice a

Basarabia, în "Vatra veche", Tg. Mureș, an X, nr.10(118), octombrie 2018, p.40.

${ }^{17}$ Ibidem. 
pământului dintre Carpați la patria-mumă. Cu puterea lui vizionară, în asemenea termeni concepea și articolele lui din ziarul „Timpul”, care dovedesc că jurnalistul bucureștean era mereu atent la seismele politice din societatea românească transilvană. Spre exemplificare, ne-am oprit la un singur eveniment consemnat de Eminescu. În zilele de 12-14 mai 1881 la Sibiu se adunaseră reprezentanții românilor din ținuturile Ardealului și Țării Ungurești locuite de români ca să se consulte cu privire la atitudinea ce urma să o ia românii în fața alegerilor pentru Camera din Pesta. Consemnat cu toată precizia în articolul său din ziarul bucureștean, programul Partidului Național-Român cuprindea punctele: 1 . Recâștigarea autonomiei Transilvaniei; 2. Introducerea limbii române ca limbă oficială a administrației și justiţiei în ținuturile locuite de români; 3. Numirea de funcționari români sau, de neromâni, numirea acelora cari știu scrie și vorbi limba română; 4. Revizuirea legii asupra naționalităților; 5. Autonomia bisericilor şi școalelor confesionale; 6 . Crearea unei legi electorale pe baza sufragiului universal sau cel puțin investirea cu drept electoral a oricărui cetățean ce plătește o dare direct;

7. Colaborare cu cei ce țin seamă de interesele și bunăstarea poporului. Pentru punerea în practică a acestui proiect politic, urma să se redacteze un memorand explicativ, tradus în franceză, germane și maghiară, intitulat Memorial compus și publicat din insărcinarea Conferinței generale a reprezentanților alegătorilor români, adunați la Sibiu în zilele de 12, 13, 14 mai st.n. 1881.

Ziaristul M. Eminescu comentează concluziv semnificația unei asemenea reuniuni, exprimându-și opinia cu claritate în această problemă majoră a vieții politice românești:"Pentru noi nu e îndoială că consângenii noștri din Ardeal vor izbuti a obține de la Coroană și de la împrejurări realizarea întregului lor program, pentru că presiunile maghiarilor, departe de-a le folosi

${ }^{18}$ M. Eminescu, în "Timpul", din 28 oct. 1882, în Opere, XIII, Publicistică, 18821883, 1888-1889, Editura Academiei R.S.R, acestora, au trezit și mai adânc sentimentul național al vrednicului și statornicului popor românesc. Observăm cu bucurie că, chiar în acele ținuturi unde sufletul părea mai adormit, un spirit nou, dătător de viață, s-a deșteptat. Cine are dreptate la urma urmelor nu este pretinsul drept istoric sau dreptul public, durat în favorul unei singure naționalități, a celei maghiare, cine are dreptate este realitatea etnologică, este adevărul. În numele adevărului și sub suflarea lui binefăcătoare e scrisă și această lucrare și, pentru că niciodată în cursul istoriei n-am văzut adevărul învins ci pururea învingător, de-aceea și acum putem prezice că, per ardua ad astra, cauza română va triumfa." 18 M-a încântat să descopăr o formă mai rară a dictonului "Per aspera ad astra", aşa cum Seneca îl folosise în tragedia Hercule furios. Cuvântul ,ardua” cu sensul de căi abrupte are aceeaşi semnificaţie ca și „aspera”. Dictonul latin astfel aşezat în comentariul concluziv prevenea pe compatrioții săi transilvăneni că împlinirea unui asemenea ideal naţional cere o luptă tenace, de bărbaţi dârji și neînfricaţi.

Adevărul este că Eminescu credea în legitimitatea luptei românilor din toate provinciile istorice pentru unire, acțiune concertată în care un punct de sprijin ferm îl găseau în credința creștină al cărei efect benefic de busolare morală și spirituală a omenirii este exprimat în termini fermi:'Iată două mii de ani aproape de când ea au ridicat popoare din întuneric, le-au constituit pe principiul iubirii aproapelui, două mii de ani de când biografia fiului lui Dumnezeu e cartea după care se crește omenirea. Învățăturile lui Buddha, viața lui Socrat și principiile stoicilor, cărarea spre virtute a chinezului Lao-tse, deși asemănătoare cu învăţămintele creștinismului, n-au avut atâta influență, n-au ridicat atâta pe om ca Evanghelia, această simplă și populară biografie a blândului nazarinean, a cărui inimă au fost străpunsă de cele mai mari dureri morale și fizice și nu pentru el, pentru binele și mântuirea altora." 19

1985, p. 212.

${ }^{19}$ M. Eminescu, Și iarăși.... În "Timpul ", 12 aprilie 1881, Vezi M. Eminescu, Opere, 
$\mathrm{Nu}$ este de mirare că în finalul articolului Din Transilvania, publicat în 3 ianuarie 1880 în ziarul "Timpul" din capitală Eminescu cele două coloane ale susţinerii luptei pentru împlinirea ființei noastre naționale: "UNITATE DE LIMBĂ, UNITATE DE BISERICĂ, IATĂ ÎN SCURTE VORBE UN ÎNTREG PROGRAM PENTRU APĂRAREA NAȚIONALITĂȚEI ROMÂNE AMENINT,ATE. ${ }^{20 "}$ (s.n.) Geniala minte politică a lui Mihai Eminescu a preconizat cu aproape patru decenii înainte liniile unui program de luptă națională românească ce avea să se împlinească în anul Marii Uniri, 1918.

\section{PAȘI DECIȘI SPRE MAREA UNIRII}

La început de secol XX, Basarabia a fost prima provincie care a aderat la actul Marii Uniri, prin cel dintâi plebiscit, organizat imediat ce Lenin a dat decretul privind dreptul la autodeterminare a popoarelor din imperiul rusesc. Spre surprinderea lui și a Ucrainei, care intenționa să ocupe niște zone din țara vecină, Republica Democratică Moldovenească, declarată în 24 ianuarie 1918 pe teritoriul ocupat de Rusia în 1812, s-a eliberat cerând la 27 martie 1918 prin votul Sfatului Țării de la Chișinău alipirea de România. În amintirea acestui moment național de istorică importanță, Parlamentul țării noastre a decretat data de 27 martie zi națională a românilor. Aceeași decizie a luat-o Bucovina de Nord în 28 noiembrie 1918, când la Cernăuți s-a cerut unirea cu țara.

Al treilea plebiscit se va organiza la Alba Iulia în 1 Decembrie 1918, decizie prin care Transilvania revenea la România.

La 29 septembrie/12 octombrie1918 Comitetul Executiv al Partidului Naţional Român din Transilvania, întrunit la Oradea, adoptă în unanimitate o declarație, redactată de Vasile Goldiș, privind hotărârea națiunii române din Transilvania de a se aşeza, ,printre națiunile libere", în temeiul dreptului ca fiecare națiune să dispună liber de soarta sa. Se revendică recunoașterea conducerii P.N.R.

vol. XIII, Publicistică,

lianuarie -31 decembrie 1881, p. 134.

${ }^{20}$ Idem, Din Transilvania, în vol. Ne e silă ca organ provizoriu de conducere a Transilvaniei. Se constituie un „Comitet de acțiune", cu sediul la Arad, avându-l în frunte pe Vasile Goldiș. 5/18 octombrie1918 Declarația de independență a Transilvaniei, adoptată în ședința de la Oradea, este citită în Parlamentul de la Budapesta de dr. Alexandru Vaida-Voevod. 14/27 octombrie1918 Deputații români bucovineni din Parlamentul vienez, foștii deputați din Dieta Bucovinei, primarii români din localitățile Țării de Sus a Moldovei, împreună cu alți reprezentanți ai provinciei istorice s-au întrunit în Sala Mare a Palatului Național din Cernăuți și au hotărât constituirea Adunării Constituante.

Adunarea alege un Consiliu Național condus de Iancu Flondor, Dionisie Bejan, Doru Popovici și Sextil Pușcariu vicepreședinți, Vasile Bodnărescu, Radu Sbierea şi Laurent Tomoioagă — secretari. 5/18 noiembrie 1918 - Manifest către popoarele lumii, -din Transilvania privind convocarea la 18 noiembrie/1 decembrie a Marii Adunări Naționale la Alba Iulia. 9/22 noiembrie 1918 - Consiliul Național Român Central din Transilvania cere, ultimativ, guvernului maghiar să-i recunoască puterea deplină asupra teritoriului Transilvaniei. $15 / 28$ noiembrie 1918 - Congresul Bucovinei hotărăște în unanimitate „Unirea necondiționată și pentru vecie a Bucovinei, în vechiile ei hotare până la Ceremuș, Colacin și Nistru, cu Regatul României”. 1 decembrie 1918 - Are loc, în sala Casinei din Alba Iulia, Adunarea Națională, cu participarea a 1.228 de delegați (deputați) aleși. Gheorghe Pop de Băsești, președintele Partidului Naţional Român, declară Adunarea Națională de la Alba Iulia „constituită și deschisă”. Vasile Goldișrostește cuvântarea solemnă, încheiată $\mathrm{cu}$ un proiect de rezoluție, care începe cu cuvintele: „Adunarea Naţională a tuturor românilor din Transilvania, Banat și Țara Ungurească, adunați prin reprezentanții lor îndreptățiţi la Alba Iulia în ziua de 1 decembrie 1918, decretează unirea acelor

(Scrieri politice), Editura Soroc, București, 1991, p. 155. 
români și a tuturor teritoriilor locuite de dânșii cu România".

Proiectul de rezoluție este adoptat cu ovații prelungite. Se vede cum România se uneşte dinspre margini spre centru, susținută de românii de la Paris, New York, Roma etc. În acest context nu trebuie să ne mire elanul din această scurtă prefață a ediției Eminescu scoasă de către Biserica Ortodoxă Română la Arad: Edițiile poeziilor lui Eminescu s-au epuizat deja înainte de război. Cele nouă nu mai pot pătrunde la noi în urma împrejurărilor nefaste. Publicul însă ni le reclamă întruna, iar noi - reuşindu-ne să le adunăm - le punem la dispoziţia on. public cetitor. Fie ca ideile și concepțiile profunde ale nemuritorului Eminescu să străbată în sufletele tuturor fiilor noştri şi din atâtea idei sorbind energia renaşterii, să ne nutrim și însuflețim și la zilele mari de acum. Arad, Decembrie 1917 Editura. Cartea, puțin cunoscută, abia semnalată în Bibliografia M. Eminescu, se deschide cu Criticilor mei, după care urmează poezia lui Eminescu Rugăciune. În interior găsim, desigur, Doină (De la Nistru pân' la Tisa). Cuprinsul este organizat după gustul acestui redactor care nu semnează, probabil directorul editurii, desigur inspirat de poziția tranşantă pentru unire a lui Vasile Goldiş.

$\mathrm{Nu}$ este, desigur, un răspuns la poziţia Blajului care, din 1892 începând, a pornit, chiar fără să vrea, construirea „Galaxiei Grama" ce va strânge în ghiocul ei atâtea animozităţi şi incompatibilități - naturale, poate, - cu Eminescu; sau, dacă judecăm că se deschide cu „Criticilor mei”, poate fi și un asemenea răspuns, dar tăcut, neafișat. Nu asta interesează aici. De altfel, dialogul nu va rămâne între sutane, va anima întreaga noastră cultură majoră. Nici greșelile de tipar nu au prea mare importanță, nici sumarul amestecat, litera de tipar amestecată și ea etc. Important este că cititorii au cam toate temele eminesciene, desfășurate după simbolica Rugăciune a poetului, sufletul ardelean fiind răscolit și de suflul eminescian, în aceste zile grele, de decizii ce implică lupta. Prin această carte Eminescu a fost prezent ca actualitate materială, ca tipăritură recentă, în anul Unirii celei Mari' ${ }^{21}$, drept pentru care se cuvine să amintim fapta cea bună.

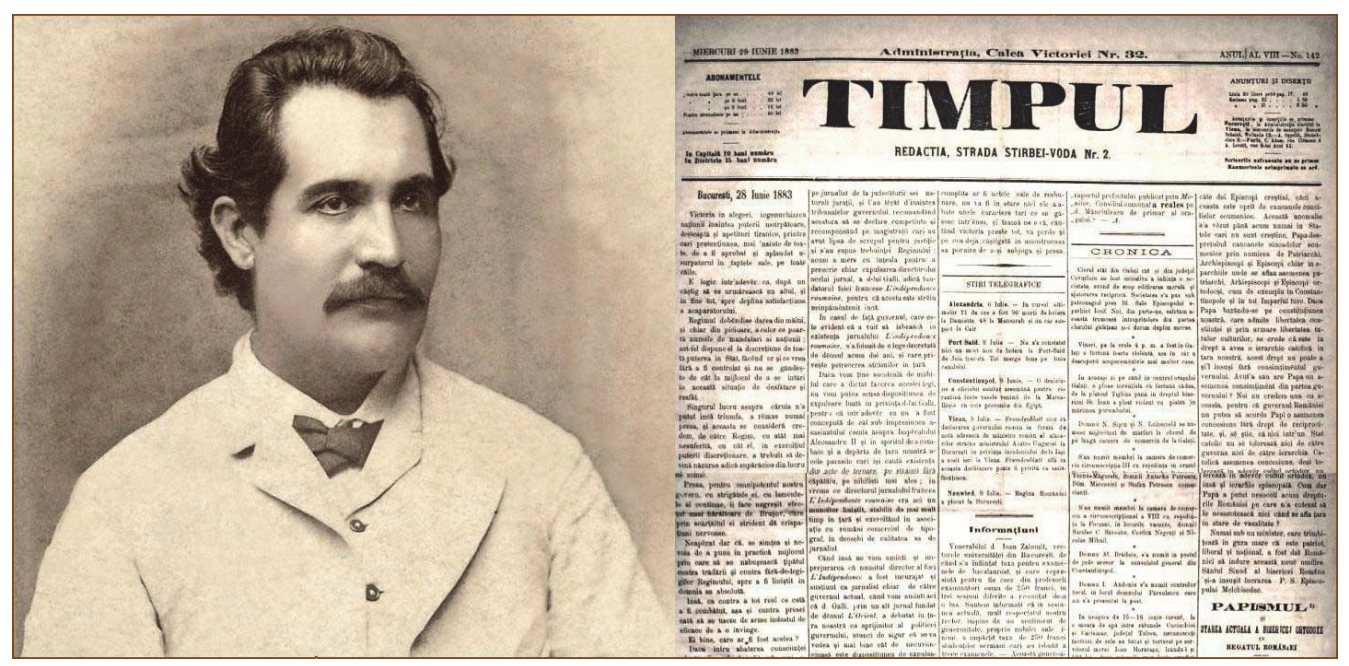

\footnotetext{
${ }^{21}$ Această comunicare științifică a fost susţinută la Simpozionul Unirii Principatelor Române, ediția a XXV-a, la Sala socială a Bisericii "Sf. Petru și Pavel”, Astoria, New York, în comunitatea românilor la 21 ianuarie 2018. Ea a fost reluată în 11 martie
}

2018 în comunitatea românilor din statul Michigan la Biserica "Sf. Teodora" de la Sihla. La Congresul ARA de la Cluj-Napoca a fost prezentată în 25 mai 2018. 